PS-060-2

臨床病期 I 期肺癌に対する胸腔鏡手術一現在の評価 と意義一

福岡大学医学部呼吸器・乳腺内分泌外科

平塚 昌文, 宗像 光輝, 巻幡 聰, 吉永 康照, 山本 聡, 白石 武史, 岩崎 昭憲, 白日 高歩

目的：肺癌治療において胸腔鏡手術（Video-assisted thoracic Surgery = VATS）が占める役割は多大である．現在までの評価について1) 術式，2）手 術成績，3）トレーニング・システム等の問題点，評価を取り上げ検討を加え た. 成績 : 1994 2005年までの clinical-I 期肺癌160例についてVATS 肺葉切 除81例と通常開胸79例の比較を行った. 12例に局所再発が見られ，8例が VATSによるもの，4例が通常開胸によるものであったが有意差はなかった $(\mathrm{p}=0.229)$. 5生率は前者が89.1\%，後者が77.7\% ( $\mathrm{p}=0.149)$ であり，多変量解 析ではリンパ節転移と左右別発生で左側発生に有意な再発パターンが見られ た．技術的な習熟が得られた2003年以降 IA 期肺癌に対して胸腔鏡のみで終 始する完全胸腔 鏡手術 (Completely Thoracoscopic Lobectomy/ Segmentectomy）を開始し，これまでに20例に実施，全ての症例で術中，術 後の合併症なく, リンパ節郭清も通常開胸と同等に完遂し得た，術後疼痛の VAS 比較でも通常開胸より有意に少ない結果であった．肺癌の胸腔鏡手術 習得については，工学分野との提携により熟練者と初心者との比較試験を基 に改良を加えた New Simulation Model を開発しドライ・ラボでの利用が評 価されると考える。結語：StageI 肺癌は技術的なレベルアップにより肺葉 切除，区域切除等での根治が可能であり，完全胸腔鏡下も一つの手術法にな りうる.またその為の修練モデルでのトレーニングが有意義である. \section{PS-060-4 術後肺合併症からみた肺癌治療における胸胫鏡手術}

\section{長崎大学医歯薬総合研究科腫瘍外科}

松本 桂太郎, 田川 努, 中村 昭博, 山崎 直哉, 土谷 智史, 橋爪 聡, 田口 恒徳, 古川 克郎, 宮崎 拓郎, 永安 武

【目的】胸腔鏡補助下手術はその低侵襲性から一期肺癌手術に対して広く行わ れているがその有用性については議論もある。 今回特に術後肺合併症から胸 腔鏡下手術の役割について検討した.【対象】胸腔鏡補助下手術を導入した 1996年〜2005年における肺癌切除症例811例を対象とした. 胸腔鏡下補助下 手術 ( $\mathrm{V}$ 群) 447例，通常開胸手術 ( $\mathrm{N}$ 群) 364例，全摘22例，葉切606例，区 切・部切175例, 他8であった.【結果】肺合併症発生率は $\mathrm{V}$ 群 $16.1 \%, \mathrm{~N}$ 群 $24.1 \%(<0.0001)$ と有意に V 群が良好であり, 呼吸器合併症発生において単 変量解析にて有意に危険因子であったのは年齢, 性別, PS, 契煙, 術前呼 吸器合併症, 呼吸機能 FEV1.0, 手術時間, 出血, VATSの有無であり, 多 変量解析にて VATS 無 (通常開胸) は独立した危険因子であった，術式を一 肺葉切除以下，PS0，1症例に背景を合わせた肺合併症の内訳は，V群 $(\mathrm{n}=403): \mathrm{N}$ 群 $(\mathrm{n}=322)$ で肺胞瘦 $31 \quad(7.7 \%): 25(7.8 \%)$ ，喀痰排出困難 13 $(3.2 \%): 22(5.1 \%)$ ，肺炎6 $6(1.5 \%): 9(2.7 \%)$ ，無気肺5(1.2\%) : 8 $(2.4 \%)$ ，間質 性肺炎 $1(0.2 \%): 3(0.9 \%)$, 肺血栓塞栓症 $0(0 \%): 3(0.9 \%)$, その他 $10(2.4 \%)$ : $9(2.7 \%)$, 計 $66(16.4 \%): 79(24.5 \%)(\mathrm{p}=0.006)$ と肺胞瘦発生では差がみられな かったが, 全体ではVATS 群で肺合併症が有意に少なかった.【結語】肺癌 に対する胸脘鏡補助下手術は術後合併症からの評価でも有用であることが示 された，ただし，術後肺胞瘦の改善には寄与しておらず，技術・器具の向上 により肺胞淖を改善することで肺癌に対する胸腔鏡補助下手術を標準化でき 得る可能性がある。

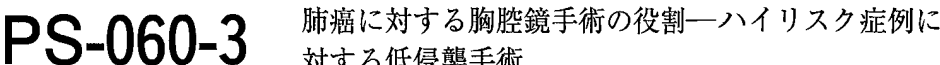 対する低侵襲手術}

東京綕恵会医科大学呼吸器外科

尾高 真, 矢部 三男, 松平 秀樹, 佐藤 修二, 森川 利昭

胸腔鏡手術の是非を問う議論が続いているが肺癌に対する胸腔鏡手術の予後 に関する長期成績が従来の開胸手術に劣らないという報告が示されるように なったささらに進んだ胸膛鏡手術の役割として超高齢者，肺気腫合併肺癌な どハイリスク患者に対する低侵襲手術の提供による手術適応の拡大，合併症 の軽減, 早期社会復帰の実現であろう。癌根治性と低侵襲性のエビデンスの 構築が急がれる。【目的】ハイリスク肺癌症例に対する胸腔鏡手術の有效性を 検討した.【対象】当院では2005年8月から完全鏡視下肺葉切除術を施行して いる. 現在までに胸腔鏡による肺切除術を施行した79例の中で75歳以上の高 齢者5例，重症肺気腫合併症例17例を対象とした (VATS 群)．2002年以降開 胸術による肺切除を行ったハイリスク 20 例と比較した.【結果】胸膜癒着, 葉 間不全分葉など手術手技に難渋する症例を認めたが，完全鏡視下にて16例手 術完遂可能であった，1例で開胸術へ変更した，重篤な術中合傡症を認めな かった。平均手術時間は298分, 出血量 $159 \mathrm{ml}$, ドレーン留置期間 3.5 日, 術 後在院日数は7.9日であった. VATS 群で1例に術後肺漏遷延，1例に心房細 動を認めた. その他は術後合併症を認めなかった．比較群では術後在院日数 20.8日，重篤な術後合併症を7例に認め，5例で気管切開術などの処置を要し， 1例に在院死を認めた.【考察】胸腔鏡手術はハイリスク肺癌症例に対して低 侵襲手術により早期回復を図ることが可能であり，合併症防止，早期退院が 可能であった．重症肺気腫を有するようなハイリスク症例こそ胸腔鏡手術の 有効性，優位性を発揮できるものと考える．肺癌根治性を含めた手術の妥当 性を今後も検討していきたい.

\section{PS-060-5 高龄者肺癌における胸䅅鏡下肺葉切除の有用性}

\section{岡山赤十字病院呼吸器外科}

森山 重治, 村岡 孝幸

【はじめに】当科では臨床病期 I 期に対しては標準手術となっており，昨年も 全肺癌の約 $90 \%$ VATS 下に行われた，原発性肺癌に対するVATS の役割 には, 臨床病期 I 期に対する積極的根治手術と共に, poor risk患者; 特に 高齢者に対する低侵襲手術という役割があると思われる．当科における高齢 者肺癌に対するVATSの有用性を検討した.【対象と方法】1995年7月から 2006年10月までに当科で区域切除以上の根治手術を行った原発性肺癌527例 を対象とした。これを75歳未満 (A 群401例)，75歳以上80歳未満(B 群87例), 80 歳以上 (C 群 33 例) の3群に分け, 標準開胸 (ST) と VATS で術後在院期間, 術後合併症, 死亡率を比較した.【結果】術後合併症発生率はST $27.6 \%$, VATS $16.1 \%$ と $<0.05$ で有意にVATSが少なかった，手術死亡率は ST $3.4 \%$, VATS $1.4 \%$ と < 0.001 で有意にVATSが少なかった，術前合併疾 患保有率は A 群 $27.8 \%$, B 群 $43.2 \%$, C 群 $40.0 \%$ で, B, C 群が A 群に比して 有意に高率であった. 各群別の術後合併症発生率を見ると, A 群ではST 28.7\%, VATS $18.1 \%$ で p <0.05でVATSが有意に術後合併症が少なかった が, B 群ではST $23.5 \%$, VATS $25.9 \%$ と差はなく,C 群ではST $66.6 \%$, VATS $18.2 \%$ でVATSが良好であったが，症例数が少ないため統計学的有 意差はなかった，術後在院期間は A 群でST 16.2日, VATS 9.6日, B 群で ST 13.5日，VATS 10.8日，C群でST 16.0日，VATS 10.6日で，いずれの年 代でも VATS が術後在院期間が短く，高齢者で術後在院期間が特に長くな るということはなかった【結語】VATSはSTに比して術後合併症, 死亡率 が低く，高齢者に対しても在院期間を延長することなく有用であった. 